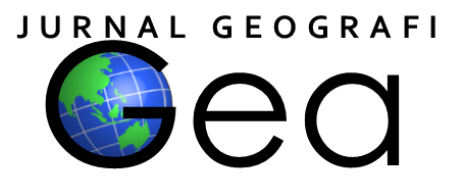

\title{
ANALISIS KONDISI MUARA KALI PORONG AKIBAT SEMBURAN LUMPUR SIDOARJO MENGGUNAKAN CITRA LANDSAT TAHUN 2014-2017
}

\author{
Yossika Dwi Permatasari ${ }^{1}$, Nurul Priyantari ${ }^{2}$, Bowo Eko Cahyono ${ }^{3}$ \\ 1,2,3 Jurusan Fisika, Fakultas Matematika dan Ilmu Pengetahuan Alam, Universitas Jember \\ 1'yossikadwip@gmail.com, ${ }^{2}$ bowocahyono@gmail.com, ${ }^{3}$ nurul.geofisika@gmail.com
}

\begin{abstract}
Mudflow in Sidoarjo Regency came out periodically, so it needed an increasingly spacious shelter. Dam that is made cannot hold more and more discharge. The mud is flowed using a pipeline to Porong River, which aims to be discharged into the river mouth. Problems arise including the condition of river estuaries that are increasingly cloudy by the remains of mud material. The purpose of this study was to determine changes in the concentration of Total Suspended Solid (TSS), TSS distribution distance, and water brightness level in the Kali Porong estuary in 2014-2017. TSS concentration values become parameters of TSS changes. The results of the changes are classified according to the TSS class category. The results of the data are matched with the Sidoarjo mud disposal data by the Sidoarjo Mud Management Center (PPLS). Changes in the distribution of the concentration of Total Suspended Solid (TSS) at the Porong River estuary from 2014-2017 have an up and down value each year. In 2014 the distribution was 509,056 Ha, in 2015 it rose to 1323,124 Ha. Whereas in 2016 it fell to 714,076 ha and rose again in 2017 to 1350,210 ha. This causes fluctuating TSS concentration values. Estuary 3 becomes an estuary which always has the highest TSS distribution distance value. Estuary 3 in 2017 has the furthest distance from the research which is 4,295 km. The water brightness level of 2014-2017 in this study resulted in a value range between 4,561 m-15,432 m.
\end{abstract}

Keywords: Sidoarjo mud, Kali Porong, Landsat-8

\begin{abstract}
ABSTRAK
Semburan lumpur di Kabupaten Sidoarjo keluar secara periodik, maka memerlukan ruang penampungan yang semakin luas. Bendungan yang dibuat tidak dapat menahan debit yang semakin banyak. Lumpur dialirkan dengan menggunakan saluran pipa menuju Kali Porong, yang bertujuan dibuang ke muara sungai. Permasalahan muncul diantaranya kondisi muara sungai yang semakin keruh oleh sisa-sisa material lumpur. Tujuan dari penelitian ini adalah mengetahui perubahan konsentrasi Total Suspended Solid (TSS), jarak sebaran TSS, dan tingkat kecerahan air di muara Kali Porong tahun 2014-2017. Nilai konsentrasi TSS menjadi parameter perubahan TSS. Hasil perubahan diklasifikasi berdasarkan kategori kelas TSS. Data hasil dicocokan dengan data buangan lumpur Sidoarjo oleh Pusat Penanggulangan Lumpur Sidoarjo (PPLS). Perubahan sebaran konsentrasi Total Suspended Solid (TSS) di muara Kali Porong dari tahun 2014-2017 memiliki nilai yang naik turun di tiap tahunnya. Tahun 2014 sebaran sebesar 509,056 Ha, tahun 2015 naik menjadi 1323,124 Ha. Sedangkan pada 2016 turun menjadi 714,076 Ha dan kembali naik pada 2017 menjadi 1350,210 Ha. Hal tersebut menyebabkan nilai sebaran konsentrasi TSS mengalami fluktuasi. Muara 3 menjadi muara yang selalu memiliki nilai jarak sebaran TSS tertinggi. Muara 3 tahun 2017 memiliki jarak terjauh
\end{abstract}


dari penelitian yakni 4,295 km. Tingkat kecerahan air tahun 2014-2017 pada penelitian ini menghasilkan rentang nilai antara 4,561 $\mathrm{m}-15,432 \mathrm{~m}$.

Kata kunci: Lumpur Sidoarjo, Kali Porong, Landsat-8

\section{PENDAHULUAN}

Mud volcano atau gunung lumpur pertama kali memuntahkan semburan dalam bentuk lumpur panas dari perut bumi ke permukaan tanah pada 26 Mei 2006 hingga saat ini. Letusan lumpur panas tersebut muncul di Kabupaten Sidoarjo. Beberapa ahli geologi percaya bahwa meletusnya gunung lumpur panas tersebut disebabkan oleh bencana alam yang dipicu gempa sehari sebelum letusan itu terjadi. Letusan tersebut diduga sebagai indikasi berupa pembentukan gunung lumpur sehingga tidak dapat diprediksi kapan letusan mud volcano akan berhenti. Krisnayanti dan Agustawijaya (2014, hlm 208). Semakin hari debit lumpur Sidoarjo terus bertambah. Saat ini luas penampungan lumpur panas tersebut sudah mencapai ratusan hektar lebih. Tanggultanggul tinggi dibuat untuk menahan semburan lumpur panas agar tidak semakin meluas.

Semburan lumpur panas yang terjadi di Kabupaten Sidoarjo tersebut, mengakibatkan berubahnya fungsi utama salah satu sungai besar yang menghimpit Kabupaten Sidoarjo, yakni Sungai Porong atau yang lebih dikenal dengan Kali Porong. Semburan lumpur tersebut keluar secara periodik sehingga memerlukan ruang penampungan yang semakin luas. Kolam-kolam yang telah membendung lumpur tersebut sudah tidak dapat menahan debit yang semakin banyak. Lumpur tersebut dialirkan dengan menggunakan saluran khusus berupa pipa-pipa menuju sungai terdekat dari lokasi semburan yakni Kali Porong, yang bertujuan untuk dibuang ke muara sungai. Budianto (2017, hlm 130).

Berbagai macam permasalahan muncul setelah lumpur tersebut dibuang ke muara sungai melalui jalur Kali Porong. Permasalahan tersebut diantaranya kondisi muara sungai yang semakin keruh oleh sisasisa material yang terbawa oleh lumpur panas. Hal tersebut mempengaruhi penurunan kualitas air, vegetasi bawah air, pemukiman, bahkan sosial ekonomi di wilayah sekitar Kali Porong. Pembuangan material lumpur dalam jumlah besar dan terus menerus dapat mengakibatkan semakin tingginya tingkat kecerahan air di muara Kali Porong hingga ke Selat Madura dari pada di Kali Porong itu sendiri. Menurut Arief (2012, hlm 68) sungai, lautan, dan danau sangat penting dalam siklus kehidupan manusia. Berbagai macam pemanfaatan dari air yakni untuk sistem irigasi pertanian, bahan baku air minum, bahkan sebagai objek wisata.

Material halus berupa padatan yang menyebabkan kecerahan air disebut dengan Total Suspended Solid (TSS). Material ini tidak terlarut dan tidak dapat mengendap secara langsung. TSS terdiri dari partikelpartikel yang memiliki ukuran maupun beratnya lebih kecil dari sedimen yakni maksimal $2 \mu \mathrm{m}$ (Ferdiaz, 1992). TSS dapat mengganggu keseimbangan ekosistem di perairan yang pada akhirnya akan berdampak buruk beberapa tahun kemudian bagi kelangsungan hidup manusia, seperti pendangkalan pelabuhan, punahnya beberapa ekosistem perairan, dan kerusakan lingkungan perairan lainnya. Menurut Pahlevi (2010) pembuangan lumpur dalam jumlah besar mengakibatkan nilai TSS meningkat sehingga dapat mempengaruhi morfologi di Kali Porong, muara Kali Porong, perairan laut Sidoarjo bahkan hingga ke Selat Madura.

Berdasarkan penjelasan paragraf sebelumnya, maka perlu dilakukan suatu pengamatan secara berkala untuk menganalisis pola perubahan sebaran TSS di muara Kali Porong dan sekitarnya yang menjadi lokasi pembuangan lumpur dari tahun 2014 hingga tahun 2017. Rentang waktu tersebut diambil karena terdapat beberapa kegiatan terhadap penanganan lumpur tersebut. Mulai dari awal munculnya semburan hingga pembuangan luapan lumpur ke sungai-sungai sampai ke muara Kali Porong dan sekitarnya. Analisa perubahan kondisi tersebut, menggunakan teknologi penginderaan jauh. Teknologi penginderaan jauh tersebut dapat digunakan untuk mengetahui perubahan kondisi permukaan bumi. Perolehan data tersebut didapat dari suatu alat jarak jauh yang mengorbit di luar angkasa dengan resolusi 
temporal yang sudah ditentukan. Benda tersebut dapat disebut sebagai satelit. Satelit tersebut akan mengirimkan data yang diperoleh ke bumi berupa data citra. Data citra yang digunakan pada penelitian ini dari Land Satellite (Landsat), mengacu pada beberapa penelitian sebelumnya. Landsat memiliki resolusi temporal yang dapat digunakan untuk pengidentifikasian suatu perubahan kondisi bumi.

\section{METODE PENELITIAN}

Penelitian mengenai "Analisis Kondisi Muara Kali Porong Akibat Semburan Lumpur Sidoarjo Menggunakan Citra Landsat Tahun 2014-2017" ini diawali dengan melakukan identifikasi terhadap rumusan masalah yang akan diteliti. Penelitian ini menggunakan data citra multi temporal Landsat-8 OLI/TIRS untuk wilayah perairan muara Kali Porong hingga pesisir pantai Kabupaten Sidoarjo Provinsi Jawa Timur yang terkena dampak Lumpur Sidoarjo. Lokasi ini memiliki nilai path 118 dan row 065. Pengambilan data di path dan row memiliki pengertian yakni kode suatu wilayah dari sebuah data citra. Data citra Landsat bersifat open source dapat diunduh di portal website United States Geological Survey (USGS) secara gratis. Data yang diambil yakni akuisisi data citra Landsat-8 OLI/TIRS tanggal 29 Juni 2014, 15 Mei 2015, 17 Mei 2016, dan 20 Mei 2017. Penentuan data digunakan ditiap tahunnya yakni pada musim kemarau bulan Mei-Juni.

Koreksi radiometrik Top of Atmosphere (ToA) digunakan untuk menghilangkan pengaruh dinamika atmosfer yang terjadi serta kesalahan pada sudut elevasi matahari. Koreksi radiometrik dilakukan pada program software ErMapper. Setelah dilakukan proses pengkoreksian maka dilakukan proses cropping dan komposit RGB. Proses cropping pada daerah yang diteliti sesuai dengan koordinat yang telah ditentukan. Proses selanjutnya yaitu melakukan komposit RGB untuk memperjelas warna yang sebenarnya (true color). Gabungan band tersebut yakni band 432 yang merupakan band red, green, dan blue yang hasilnya terbentuk berupa tiga layer sesuai warna pada band.

\section{Total Suspended Solid (TSS)}

Tahap pengolahan yang pertama yaitu melakukan perhitungan nilai Total Suspended Solid (TSS) dengan menerapkan proses penajaman citra berbasis rumus. Penajaman citra ini bertujuan untuk meningkatkan kualitas citra dan memperoleh hasil gambar yang lebih jelas untuk keperluan proses analisa citra. Penajaman citra yang berbasis formula ini menggunakan persamaan rumus Syarif Budhiman (2004). Panjang gelombang dari band merah memiliki kesesuaian pada kriteria hasil citra untuk proses analisa maka band merah digunakan sebagai input. Proses penelitian untuk mendapatkan nilai TSS dari suatu data citra Landsat diolah dengan menggunakan software ErMapper dan ArcGIS. Penggunaan formula pada penentuan nilai TSS diguanakan persamaan Rumus Syarif Budhiman berikut :

$$
\begin{aligned}
& \operatorname{TSS}_{(m g / l)}=\mathrm{A}^{*} \exp ^{\left(\mathrm{S}^{*} R(0-) b 1\right)} \\
& \operatorname{TSS}_{(\mathrm{mg} / l)}=8.1744^{*} \exp ^{\left(23.738^{*} \text { band red }\right)} \\
& \text { Keterangan: } \\
& \mathrm{TSS}=\text { Total Suspended Solid }(\mathrm{mg} / \mathrm{l}) \\
& \mathrm{A}=\text { nilai konstanta rumus } \\
& \mathrm{S}=\text { nilai konstanta sedimen }(\mathrm{mg} / \mathrm{l}) \\
& \mathrm{R}(0-) \text { b1 }=\text { Irradiance reflectance input } \\
& \text { band red }
\end{aligned}
$$

\section{Jarak Horizontal Terjauh dari Muara Sungai}

Tahap pengolahan selanjutnya untuk memperoleh nilai jarak horizontal terjauh dari muara sungai pada nilai sebaran tertinggi konsentrasi Total Suspended Solid (TSS). Terdapat 3 muara yang menjadi titik acuan perhitungan jarak terjauh sebaran TSS. Pengukuran jarak dilakukan dengan cara penarikan garis horizontal dari masing-masing muara ke titik sebaran TSS terjauh dari muara. Hasil pengukuran tersebut dapat dibahas dalam analisis untuk mengetahui seberapa jauh jarak horizontal yang di pengaruhi oleh perubahan nilai sebaran TSS.

\section{Tingkat Kecerahan Air}

Tingkat kecerahan perairan merupakan suatu angka yang dapat menunjukkan seberapa jauh jarak penetrasi cahaya matahari menembus perairan yang digunakan sebagai fotosintesis oleh ekosistem perairan. Nilai 
kecerahan dinyatakan dalam meter. Kecerahan air sangat dipengaruhi oleh kekeruhan suatu perairan yang tercemar.

Langkah untuk mendapatkan nilai kecerahan, tahapannya hampir sama dengan memperoleh nilai Total Suspended Solid (TSS) namun pada penggunaan formula menerapkan persamaan tingkat kecerahan air dari Mujito, et al (1997).

$$
\operatorname{Kekeruhan}_{(m)}=17,51427-0,10925^{*} b 1
$$

Keterangan:

$$
\mathrm{b} 1=\text { Input band red }
$$

Analisis data yang digunakan pada penelitian ini meliputi perubahan nilai konsentrasi Total Suspended Solid (TSS), perubahan jarak horizontal terjauh dari muara sungai, dan perubahan tingkat kecerahan air yang ada di perairan pesisir pantai Kabupaten Sidoarjo. Perubahan nilai TSS diketahui dengan cara membandingkan perubahan hasil dari pengolahan data citra Landsat-8 OLI/TIRS tanggal 29 Juni 2014, 15 Mei 2015, 17 Mei 2016, dan 20 Mei 2017 yang dibuat dalam bentuk peta hasil dari olahan dengan menggunakan persamaan rumus Syarif Budhiman.

Rentang data tersebut memperlihatkan nilai perubahan sebaran konsentrasi TSS yang dihasilkan dan juga tingkat kecerahan air. Nilai konsentrasi tersebut yang menjadi parameter adanya perubahan nilai konsentrasi TSS. Hasil perubahan tersebut dibuat klasifikasi berdasarkan nilai TSS yang diamati melalui transformasi citra. Begitu juga dengan nilai kecerahan yang dihasilkan pada tanggaltanggal tersebut ditiap tahunnya digunakan klasifikasi kelas yang sama dengan klasifikasi TSS.

Berdasarkan data perhitungan jarak horizontal terjauh dapat di analisis pengaruh persebaran TSS pada proses persebaran dari data tanggal-tanggal pertahunnya tersebut dengan menghubungkan menggunakan data penunjang dari Pusat Penanggulangan Lumpur
Sidoarjo (PPLS) yakni data lumpur yang dialirkan menuju sungai Kali Porong.

Data jarak horizontal terjauh tersebut kemudian dirata-ratakan untuk menemukan seberapa besar pengaruh dari ke tiga muara terhadap jarak sebaran TSS.

\section{HASIL DAN PEMBAHASAN}

\section{Total Suspended Solid (TSS)}

Penelitian sebaran konsentrasi Total Suspended Solid (TSS) di wilayah muara Kali Porong ini dianalisis dengan menggunakan citra Landsat-8 OLI/TIRS tanggal 29 Juni 2014, 15 Mei 2015, 17 Mei 2016, dan 20 Mei 2017. Data yang dipilih merupakan data di musim kemarau yang memiliki rentang antara bulan Mei-Juni di setiap tahunnya. Ke tiga klasifikasi kelas konsentrasi memiliki kriteriakriteria yang dapat berkorelasi bagi kehidupan perikanan. Kelas I dengan nilai konsentrasi < $25 \mathrm{mg} / \mathrm{L}$ merupakan kelas dengan kategori tidak memiliki pengaruh yang berarti dalam dunia perikanan. Kelas II dengan nilai konsentrasi 25-80 $\mathrm{mg} / \mathrm{L}$ merupakan kelas kategori sedikit berpengaruh terhadap kepentingan perikanan. Kelas terakhir pada penelitian ini yaitu kelas III dengan nilai konsentrasi $>80 \mathrm{mg} / \mathrm{L}$ yang memiliki kriteria kurang baik bagi kepentingan perikanan.

Hasil klasifikasi yang didapatkan digunakan untuk membuat peta sebaran konsentrasi TSS pada tahun 2014, 2015, 2016 dan 2017 dengan perbedaan warna di setiap klasifikasi kelas konsentrasi tersebut. Peta konsentrasi TSS yang diklasifikasikan menjadi 3 kelas memiliki perbedaan warna di setiap kelasnya.

Kelas I dapat dilihat dengan tampilan warna biru tua. Kelas II dapat dilihat dengan tampilan warna biru dan kelas III dapat dilihat dengan tampilan warna biru muda. Adapun warna coklat pada peta sebaran konsentrasi TSS tersebut merupakan daratan wilayah Sidoarjo. Sebaran konsentrasi TSS yang diklasifikasikan tersebut kemudian dihitung luasan perkelasnya dengan rentang yang telah ditentukan.

Tabel 1. Sebaran Konsentrasi Total Suspended Solid Tahun 2014-2017

\begin{tabular}{cccccc}
\hline \multirow{2}{*}{ Kelas } & \multirow{2}{*}{ TSS (mg/L) } & \multicolumn{5}{c}{ Luas TSS } \\
\cline { 3 - 6 } & & $\mathbf{2 0 1 4}$ & $\mathbf{2 0 1 5}$ & $\mathbf{2 0 1 6}$ & $\mathbf{2 0 1 7}$ \\
\hline I & $<25$ & 509,0561 & 1323,124 & 714,0765 & 1350,21 \\
\hline
\end{tabular}




\begin{tabular}{cccccc}
\hline II & $25-80$ & 2369,711 & 2202,991 & 2012,7773 & 2027,4941 \\
III & $>80$ & 1716,728 & 1069,459 & 1868,692 & 1217,825 \\
\hline
\end{tabular}

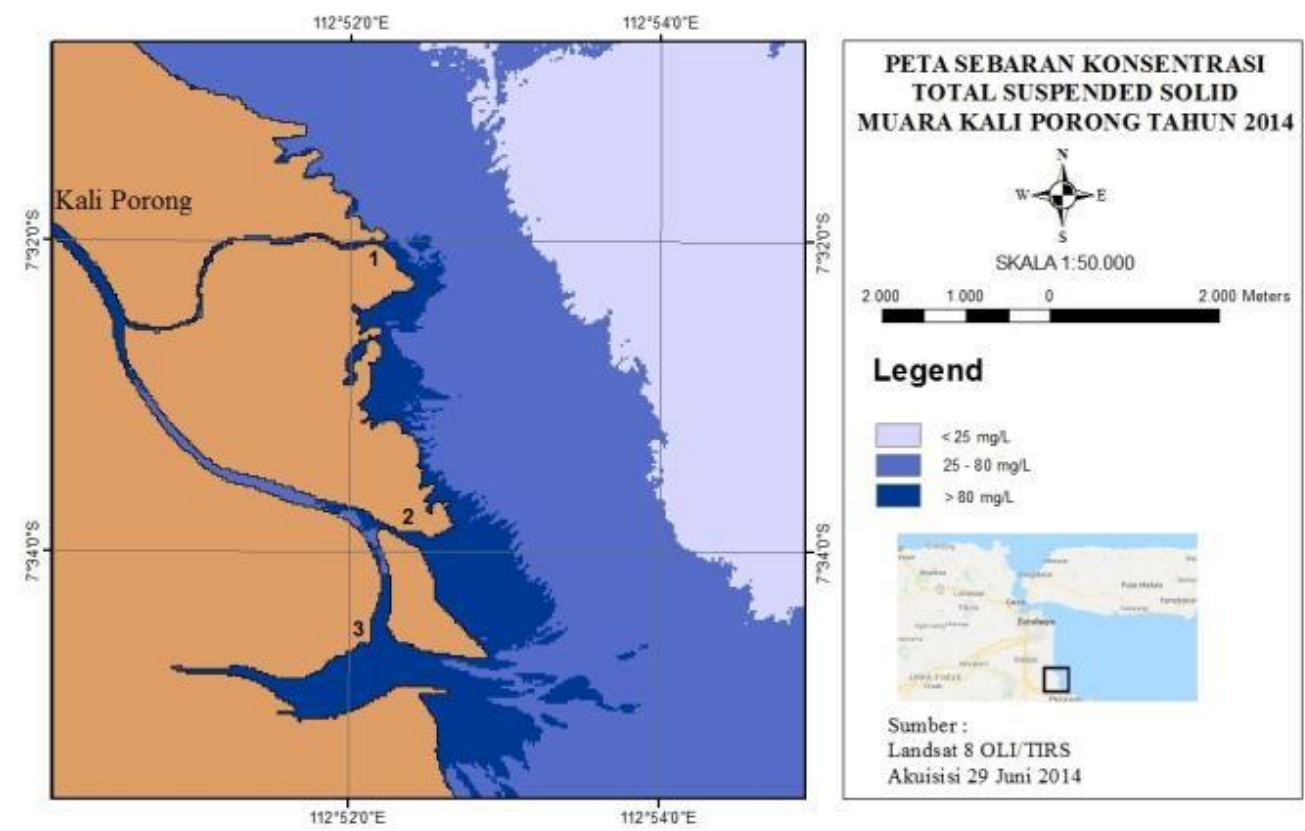

Gambar 1. Peta sebaran konsentrasi Total Suspended Solid muara Kali Porong tahun 2014

Berdasarkan Gambar 1. diketahui bahwa wilayah yang berada tidak jauh dari 3 muara Kali Porong memiliki nilai konsentrasi TSS yang masuk dalam klasifikasi kelas III. Nilai konsentrasi di wilayah tersebut memiliki nilai relatif tinggi dibandingkan dengan wilayah yang berada jauh dari 3 muara Kali Porong. Sebaran konsentrasi TSS pada kelas III ini terdapat di setiap muara Kali Porong yang merupakan jalur keluarnya buangan Lumpur Sidoarjo.

Konsentrasi TSS yang bernilai tinggi termasuk dalam kategori kelas III juga ditemukan di bibir-bibir pantai wilayah tersebut. Nilai konsentrasi tertinggi TSS pada tahun 2014 ini sebesar $91 \mathrm{mg} / \mathrm{L}$. Berdasarkan Gambar 1. dari ketiga muara tersebut muara yang memiliki konsentrasi kelas III paling banyak berada di muara 2 dan muara 3 .
Penelitian tahun 2015 menghasilkan nilai konsentrasi tertinggi TSS sebesar 98 $\mathrm{mg} / \mathrm{L}$. Nilai konsentrasi TSS ini meningkat dari tahun sebelumnya yang memiliki nilai konsentrasi tertinggi TSS sebesar $91 \mathrm{mg} / \mathrm{L}$. Namun dari kedua nilai konsentrasi tertinggi TSS pada tahun 2014 dan 2015 tersebut masuk dalam kategori kelas III yang merupakan kategori kurang baik bagi kepentingan perikanan. Pada tahun 2015, tidak hanya nilai konsentrasi TSS yang semakin meningkat, luas sebarannya juga semakin meningkat. Hal tersebut bisa diamati dari Gambar 2. dimana warna biru tua yang berada di ketiga muara Kali Porong mendominasi sepanjang bibir pantai wilayah tersebut. Kelas III yang merupakan kelas tertinggi konsentrasi TSS tahun 2015 memiliki luas sebesar 1323,124 Ha yakni hampir 2 kali lipat kenaikan dari tahun sebelumnya yakni tahun 2014 . 


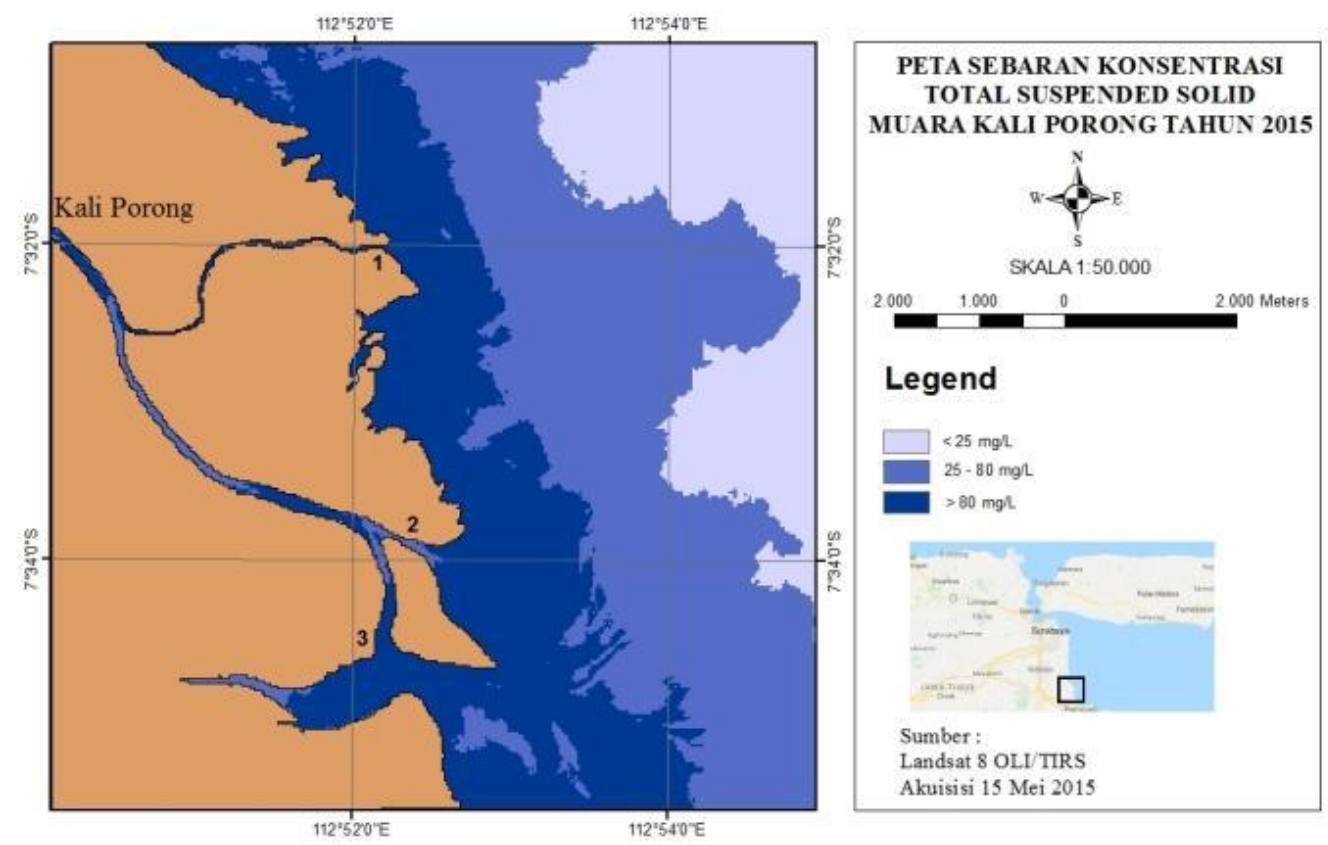

Gambar 2. Peta sebaran konsentrasi Total Suspended Solid muara Kali Porong tahun 2015

Peningkatan luas sebaran konsentrasi pada kelas III hampir di setiap bibir pantai. Ketiga kategori kelas tersebut dihitung luas keseluruhan sebaran TSSnya dari konsentrasi $<25 \mathrm{mg} / \mathrm{L}$ sampai dengan > $80 \mathrm{mg} / \mathrm{L}$ yakni memiliki luas sebesar 4595,574 Ha.

Nilai konsentrasi tertinggi TSS di muara Kali Porong pada tahun 2016 mengalami peningkatan yakni dari semula $98 \mathrm{mg} / \mathrm{L}$ menjadi $105 \mathrm{mg} / \mathrm{L}$. Namun berbeda dengan luas sebaran TSS kelas III yang semakin menurun luasnya dari tahun sebelumnya. Persebaran luas konsentrasi kelas III TSS pada tahun 2016 berada di wilayah 3 bibir muara Kali Porong dan sekitar bibir pantai wilayah tersebut.

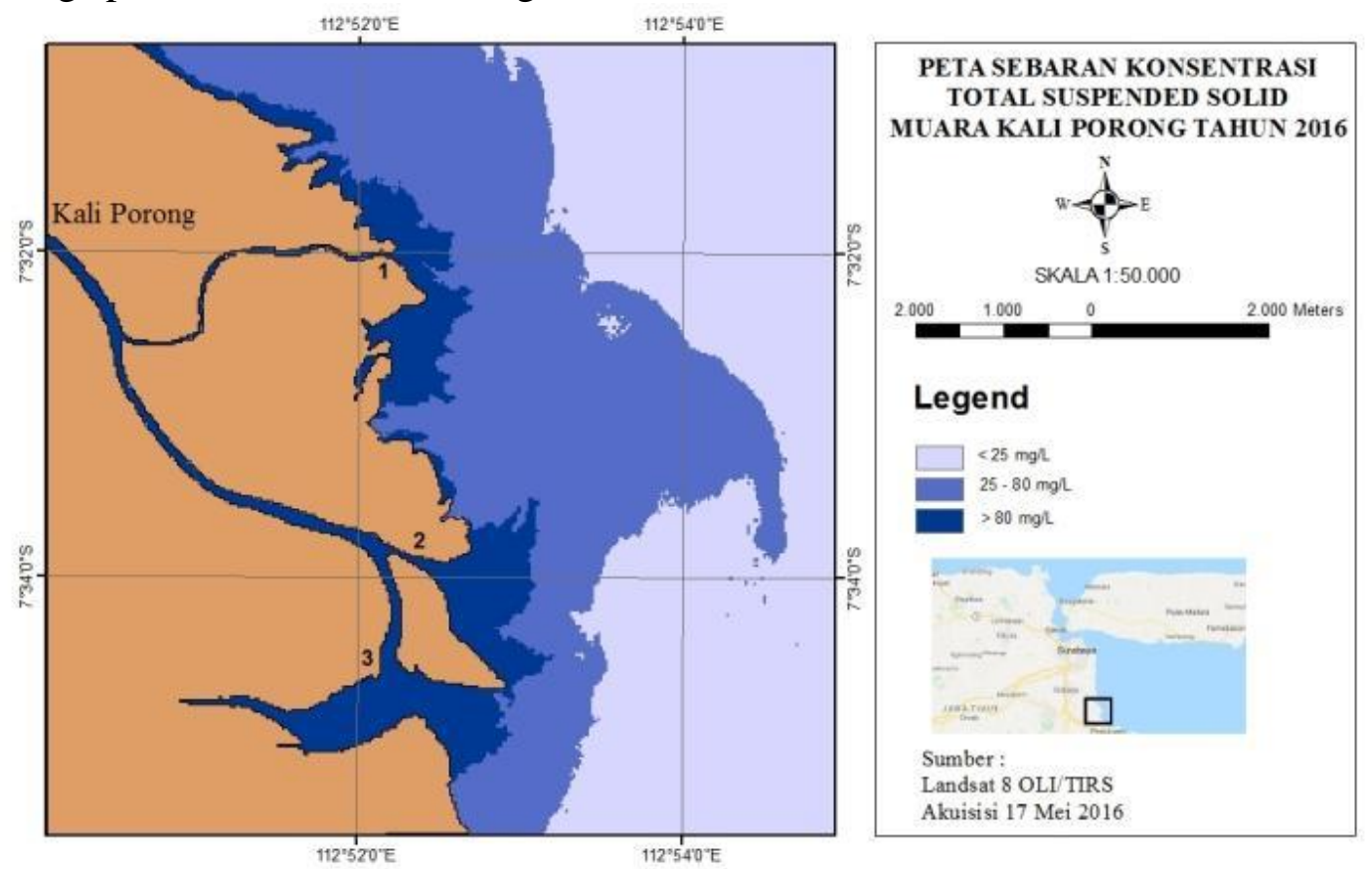

Gambar 3. Peta sebaran konsentrasi Total Suspended Solid muara Kali Porong tahun 2016

Dari Gambar 1. dan Gambar 2. dapat dilihat bahwa luas sebaran nilai konsentrasi TSS kelas III dari tahun 2014 ke 2015 mengalami peningkatan, kemudian pada
Gambar 3 ditampilkan tahun 2015 ke 2016 mengalami penurunan. Luas sebaran konsentrasi TSS kelas III pada tahun 2016 memiliki nilai hampir sama dengan tahun 
2014. Konsentrasi kelas III TSS tidak banyak mengalami penyebaran yang signifikan, sehingga konsentrasi TSS kelas IV berada tidak jauh dari ketiga muara yang merupakan

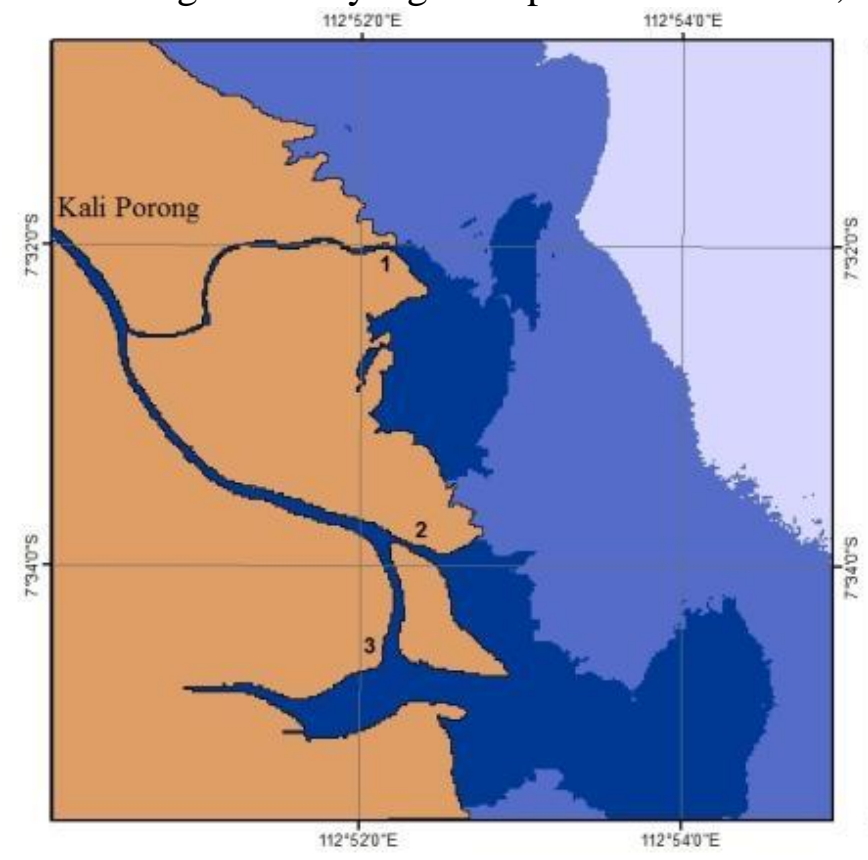

lokasi pembuangan Lumpur Sidoarjo. Nilai luas sebaran keseluruhan dari ketiga kelas konsentrasi TSS tersebut yakni seluas 4595,545 Ha.

Gambar 4. Peta sebaran konsentrasi Total Suspended Solid muara Kali Porong tahun 2017

Gambar 4. menjelaskan bahwa pada tahun 2017 didapatkan nilai konsentrasi tertinggi TSS di muara Kali Porong sedikit menurun yakni dari $105 \mathrm{mg} / \mathrm{L}$ pada tahun 2016 menjadi $103 \mathrm{mg} / \mathrm{L}$ pada tahun 2017. Sebaran pada tahun 2017 hanya terdapat di dua muara yang memiliki luas konsentrasi III besar ditunjukkan Gambar 4.4. Lokasi tersebut terletak di muara 3 yang terlihat lebih besar dari pada muara yang lain.

\section{Volume Pembuangan Lumpur Sidoarjo}

Sebaran konsentrasi kelas III dimungkinkan memiliki konsentrasi tinggi akibat dari buangan Lumpur Sidoarjo. Sebaran konsentrasi TSS mengalami fluktuasi berdasarkan klasifikasi kelas tertinggi yakni kelas III pada tahun 2014-2017 seperti yang ditunjukkan pada Gambar 5. Tahun 2014 memiliki luas sebaran konsentrasi TSS sebesar 509,056 Ha. Tahun selanjutnya yakni tahun 2015 mengalami kenaikan luas sebaran konsentrasi menjadi $1323,124 \mathrm{mg} / \mathrm{L}$. Tahun 2016 mengalami penurunan menjadi 714,076 $\mathrm{Ha}$ dan puncaknya pada tahun 2017 mengalami peningkatan terbesar yakni menjadi 1350,210 Ha.

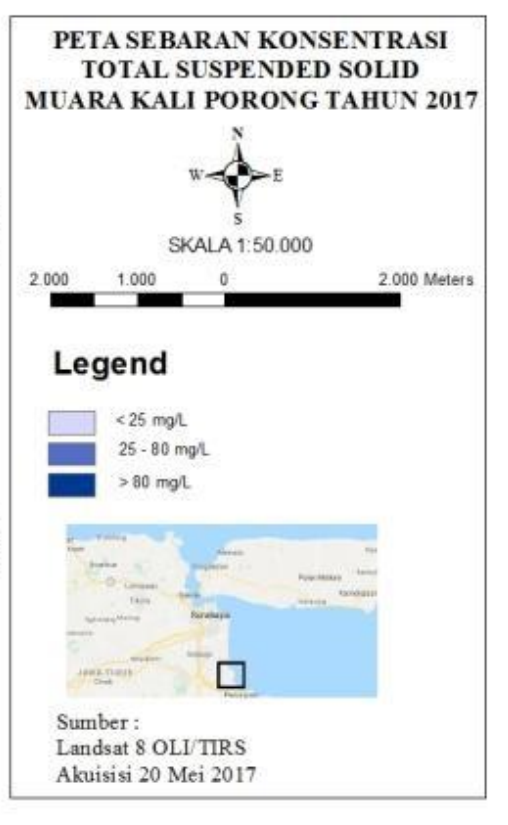

Salah satu faktor yang dimungkinkan dapat menyebabkan adanya fluktuasi luas sebaran adalah volume pembuangan Lumpur Sidoarjo. Data mengenai volume pembuangan Lumpur Sidoarjo yang dialirkan melalui Kali Porong pada tahun 2014-2017 dapat diakses di Pusat Pengendalian Lumpur Sidoarjo (PPLS). Volume pembuangan Lumpur Sidoarjo yang dialirkan melalui Kali Porong pada tahun 2014 bernilai $21.106 .033 \mathrm{~m}^{3}$. Tahun selanjutnya 2015 sebesar $40.006806 \mathrm{~m}^{3}$. Tahun 2016 sebesar $36.560 .703 \mathrm{~m}^{3}$ dan tahun 2017 bernilai 40.128.237 $\mathrm{m}^{3}$ (PPLS, 2018).

Berdasarkan Gambar 5. jumlah volume Lumpur Sidoarjo yang dialirkan menuju Kali Porong merupakan faktor yang mempengaruhi nilai sebaran konsentrasi TSS pada kelas III yang merupakan kelas tertinggi dengan konsentrasi $>80 \mathrm{mg} / \mathrm{L}$. Luasan pada klasifikasi kelas III merupakan daerah yang termasuk dalam kategori kurang baik bagi kepentingan perikanan. Hal tersebut ternyata terdapat hubungan antara besarnya luasan sebaran konsentrasi TSS kelas III di setiap tahunnya dengan volume buangan lumpur Sidoarjo yang dialirkan melalui Kali Porong. Ketika volume buangan lumpur Sidoarjo ke Kali Porong kecil maka luasan konsentrasi TSS kelas III juga 
kecil dan sebaliknya semakin banyak volume lumpur Sidoarjo yang dialirkan melalui Kali Porong maka luasan konsentrasi TSS kelas III juga semakin besar. Faktor terbesar pengaruh sebaran konsentrasi TSS di muara Kali Porong merupakan buangan Lumpur Sidoarjo.

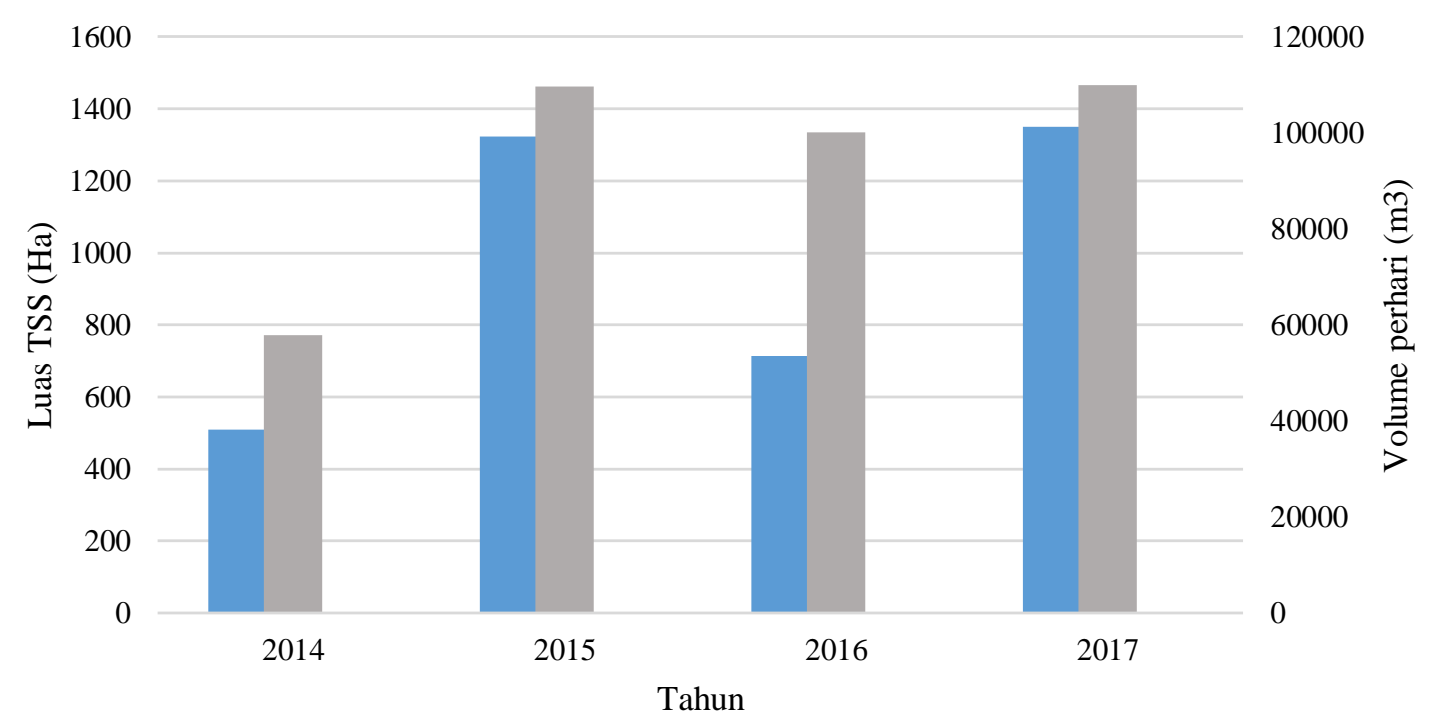

- Luas TSS (Ha) Volume perhari (m3)

Gambar 5. Grafik hubungan volume Lumpur Sidoarjo perhari yang dialirkan ke Kali Porong dengan nilai luas sebaran TSS kelas III tahun 2014-2017

Volume buangan Lumpur Sidoarjo yang dialirkan ke Kali Porong memiliki jumlah buangan yang berbeda-beda, naik turun setiap tahunnya. Gambar 5. menunjukkan bahwa jumlah volume buangan Lumpur Sidoarjo mengalami fluktuasi. Data buangan lumpur setiap tahunnya yakni pada tahun 2014 ke tahun 2015 mengalami peningkatan volume buangan yang cukup besar. Tahun 2015 ke tahun 2016 mengalami penurunan volume aliran, namun masih memiliki volume yang lebih tinggi dari pada tahun 2014. Tahun 2016 ke tahun 2017 mengalami peningkatan yang tingginya hampir menyamai volume buangan pada tahun 2015 namun sedikit lebih tinggi.

Nilai grafik yang mengalami fluktuasi tersebut dapat dihubungkan dengan luas sebaran konsentrasi TSS pada penelitian ini, karena memiliki nilai naik turun yang sama setiap tahunnya. Tahun 2014 ke tahun 2015 mengalami peningkatan, hal tersebut juga dialami oleh semakin bertambahnya volume buangan Lumpur Sidoarjo yang dialirkan menuju Kali Porong pada tahun tersebut. Tahun 2015 ke tahun 2016 yang mengalami penurunan pada sebaran konsentrasi TSS, diiringi juga turunnya volume buangan Lumpur Sidoarjo yang dialirkan menuju Kali Porong. Tahun 2016 ke tahun 2017 luas sebaran TSS mengalami peningkatan yang juga diikuti oleh meningkatnya jumlah volume Lumpur Sidoarjo.

\section{Jarak Horizontal Terjauh Sebaran TSS}

Berdasarkan peta jarak sebaran Total Suspended Solid muara Kali Porong tahun 2014, pada Gambar 6. didapatkan nilai jarak titik $A^{1}-X^{1}$ sepanjang $0,777 \mathrm{~km}$, jarak titik $A^{2}$ - $X^{2}$ sepanjang $1,546 \mathrm{~km}$, dan jarak pada titik $\mathrm{A}^{3}-\mathrm{X}^{3}$ sepanjang $2,758 \mathrm{~km}$. Gambar 7. peta jarak sebaran Total Suspended Solid muara Kali Porong tahun 2015 didapatkan nilai jarak titik $\mathrm{A}^{1}-\mathrm{X}^{1}$ sepanjang $1,048 \mathrm{~km}$, jarak titik $\mathrm{A}^{2}$ - $\mathrm{X}^{2}$ sepanjang $1,782 \mathrm{~km}$, dan pada titik $\mathrm{A}^{3}$ $\mathrm{X}^{3}$ diperoleh jaraknya sepanjang 2,486 km. Tahun 2016 yang dapat dilihat pada Gambar 8. jarak pada titik $\mathrm{A}^{1}-\mathrm{X}^{1}$ memiliki panjang $0,923 \mathrm{~km}$, sedangkan $\mathrm{A}^{2}-\mathrm{X}^{2}$ sepanjang 1,339 $\mathrm{km}$, dan pada titik $\mathrm{A}^{3}-\mathrm{X}^{3}$ konsentrasi TSS berjarak 1,343 km. Tahun 2017 dapat diamati pada Gambar 9. didapatkan nilai jarak jangkauan TSS titik $\mathrm{A}^{1}-\mathrm{X}^{1}$ yaitu sebesar $1,865 \mathrm{~km}$, pada titik muara $\mathrm{A}^{2}-\mathrm{X}^{2}$ memiliki panjang $1,534 \mathrm{~km}$, dan pada titik terjauh yakni pada titik $\mathrm{A}^{3}-\mathrm{X}^{3}$ sebesar $4,295 \mathrm{~km}$.

Keempat peta jarak sebaran konsentrasi TSS tersebut menghasilkan bahwa muara 3 memiliki dampak terjauh horizontal 
sebaran TSS menuju tengah laut. Nilai setiap tahun pada muara 3 berurutan dari tahun 20142017 yakni $2,758 \mathrm{~km}, 2,486 \mathrm{~km}, 1,343 \mathrm{~km}$, dan $4,295 \mathrm{~km}$. Hal tersebut dikarenakan pengaruh faktor pada sebaran jarak muara 3 yakni lebar sungai dan orientasi arah jalur sungai. Berdasarkan Gambar 9. dapat dilihat bahwa Kali Porong memiliki jalur aliran sungai yang bercabang dua yakni menuju muara 1 dan muara 2 dan 3.

Dari kedua percabangan sungai tersebut cabang sungai yang mengalir menuju muara 2 dan 3 terlihat lebih lebar dari pada cabang yang menuju muara 1 . Hal tersebut mengindikasikan bahwa aliran lumpur yang di buang melalui jalur percabangan 2 lebih banyak dari pada cabang yang menuju muara 1. Pada cabang muara 1 memiliki arah ke kiri, sedangkan cabang yang mengalir ke muara 2 dan 3 mengarah lurus. Sehingga dalam orientasi pengaliran air lebih mudah mengalir melalui jalur lurus (cabang 2 yakni muara 2 dan 3) dari pada melalui jalur yang berkelok pada cabang muara 1 .

Hal itu dipengaruhi oleh orientasi arah alirannya yang lurus. Gambar 9. menunjukkan bahwa cabang 2 Kali Porong tersebut terdapat 2 cabang sungai lagi yang menuju muara 2 dan

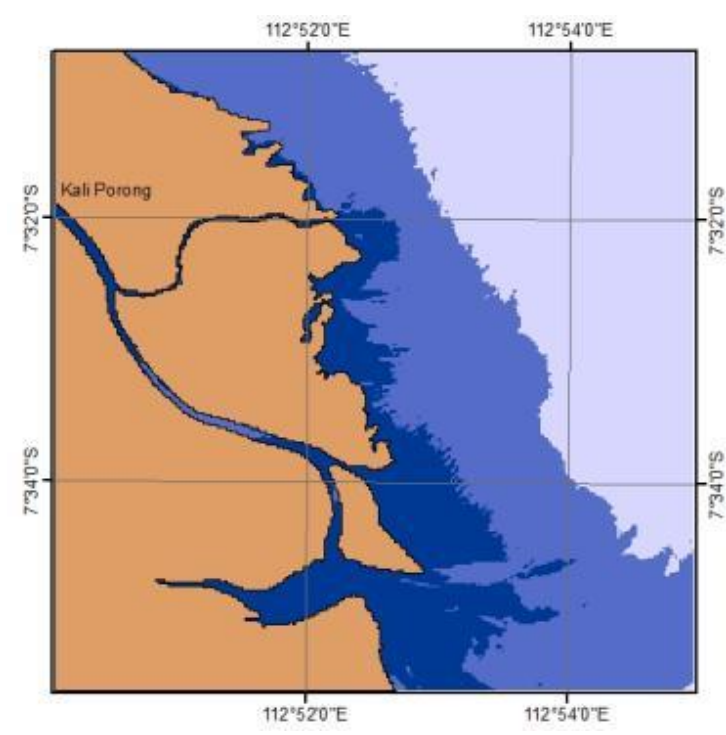

(a) Tingkat kecerahan; muara 3. Berdasarkan Gambar 9. dapat dilihat mengenai lebar sungainya lebih besar yang berada pada muara 3 dari pada muara 2 .

Dapat dianalisis bahwa jalur sungai pada muara 3 merupakan jalur sungai yang lebih lebar dari pada jalur sungai yang lain. Rata-rata jarak horizontal sebaran TSS pertahun yakni pada tahun 2014 sebesar 1,693 $\mathrm{km}$, tahun 2015 sebesar $1,772 \mathrm{~km}$, tahun 2016 sebesar 1,201 km, dan pada tahun 2017 yakni sebesar 2,564 km.

\section{Tingkat Kecerahan Air}

Nilai kecerahan air dikelompokkan sesuai konsentrasi kelas TSS sehingga diketahui korelasi nilainya sesuai dengan kelas TSS. Konsentrasi TSS kelas I memiliki warna biru muda, begitu juga dengan tingkat kecerahan air pada kelas I yang memiliki nilai kecerahan $>12 \mathrm{~m}$. Konsentrasi TSS kelas II berwarna biru sama halnya dengan warna pada tingkat kecerahan air kelas II dengan rentang 5-12 m. Kelas III konsentrasi TSS memiliki warna biru tua sama dengan kelas III pada tingkat kecerahan air dengan nilai kecerahan > $5 \mathrm{~m}$. Warna tersebut bermakna semakin pekat semakin rendah tingkat kecerahan air dan semakin tinggi konsentrasi TSS.

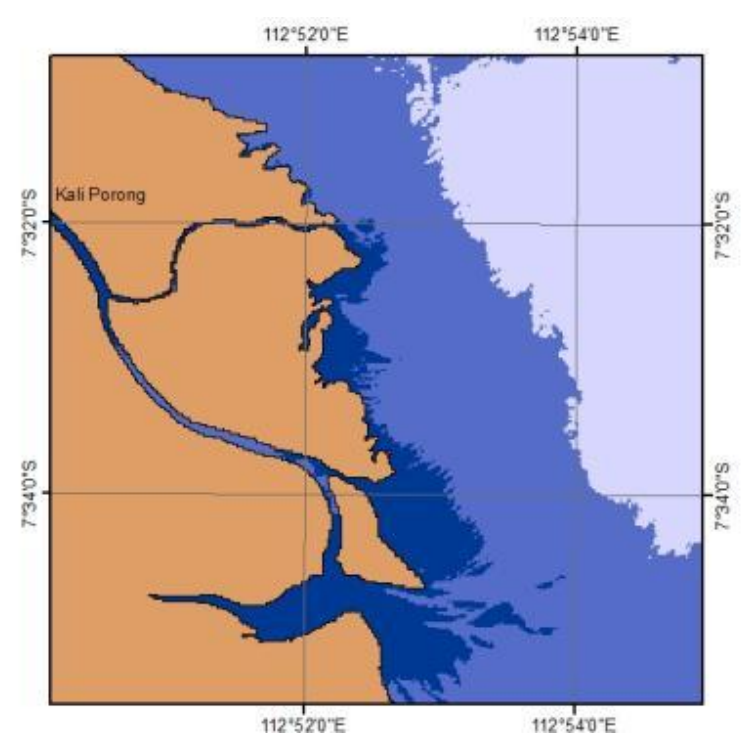

(b) Konsentrasi TSS

Gambar 10. Tingkat kecerahan dan konsentrasi TSS tahun 2014 


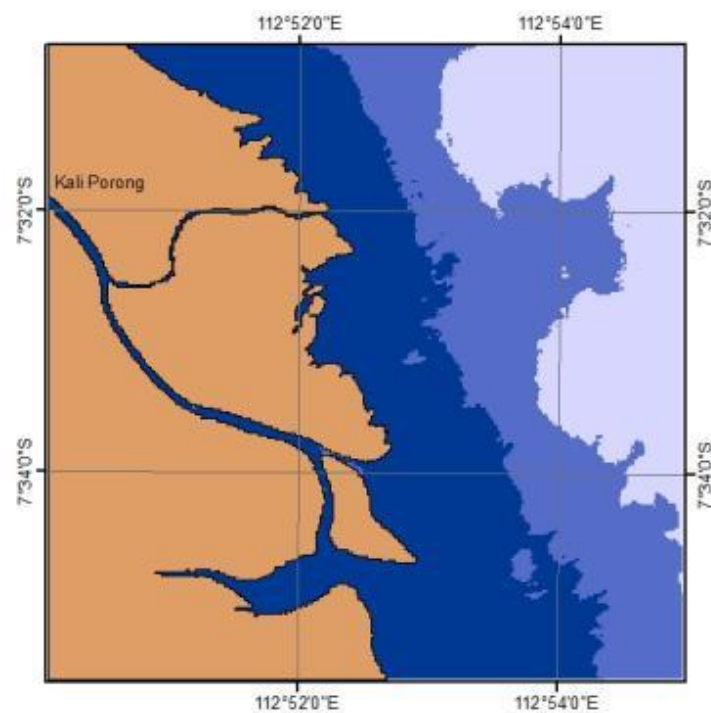

(a) Tingkat kecerahan;

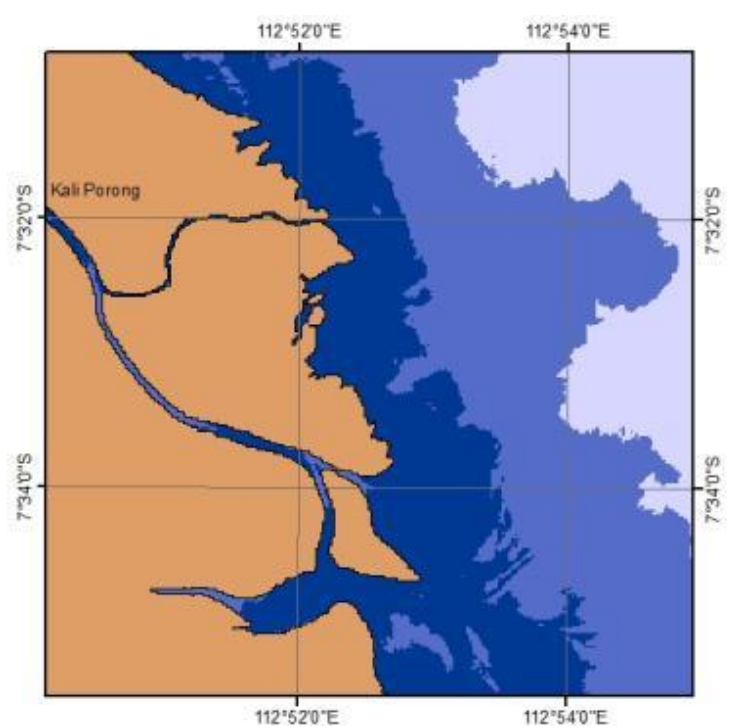

(b) Konsentrasi TSS

Gambar 11. Tingkat kecerahan dan konsentrasi TSS tahun 2015

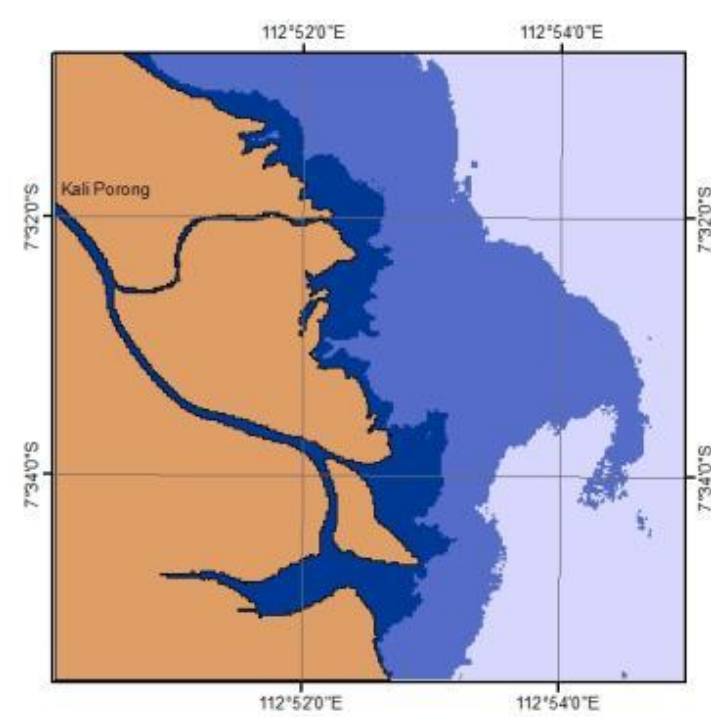

(a) Tingkat kecerahan;

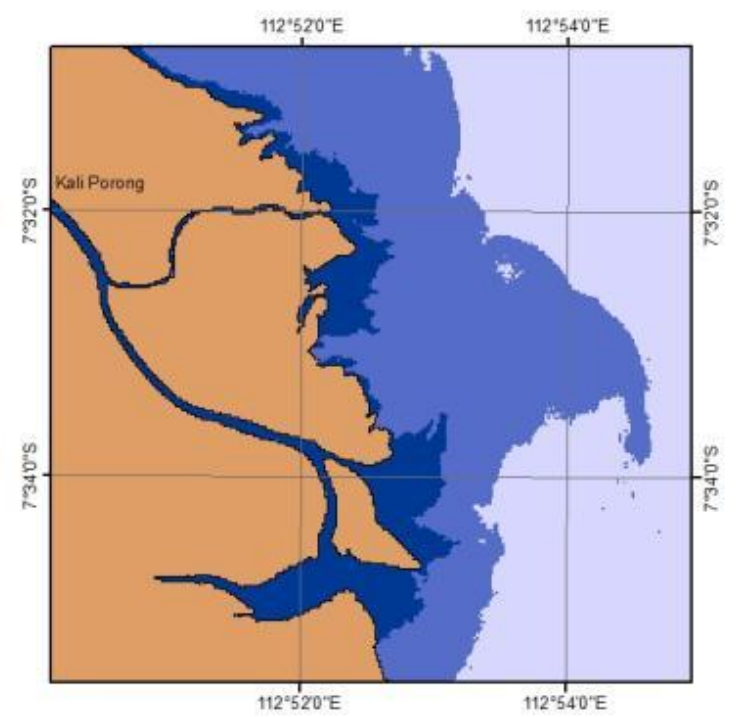

(b) Konsentrasi TSS

Gambar 12. Tingkat kecerahan dan konsentrasi TSS tahun 2016

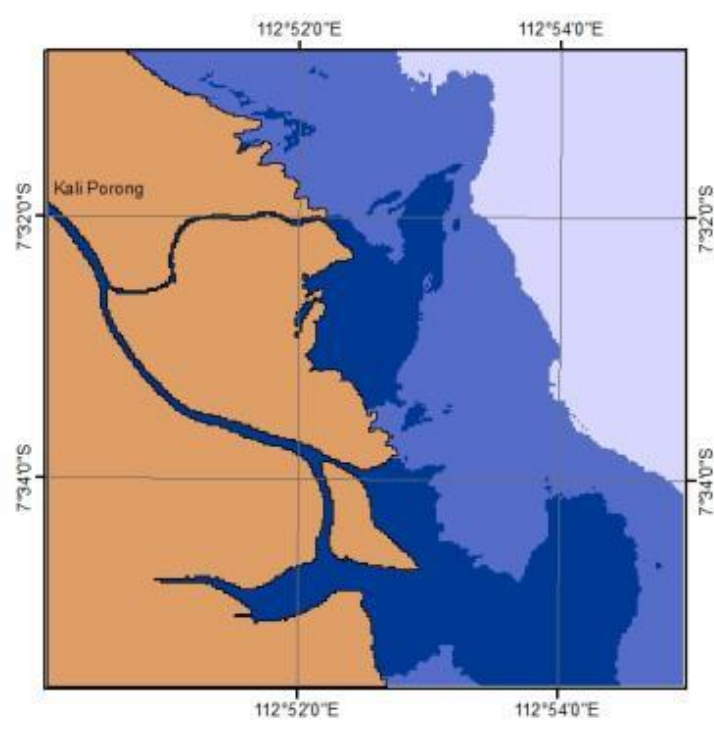

(a) Tingkat kecerahan;

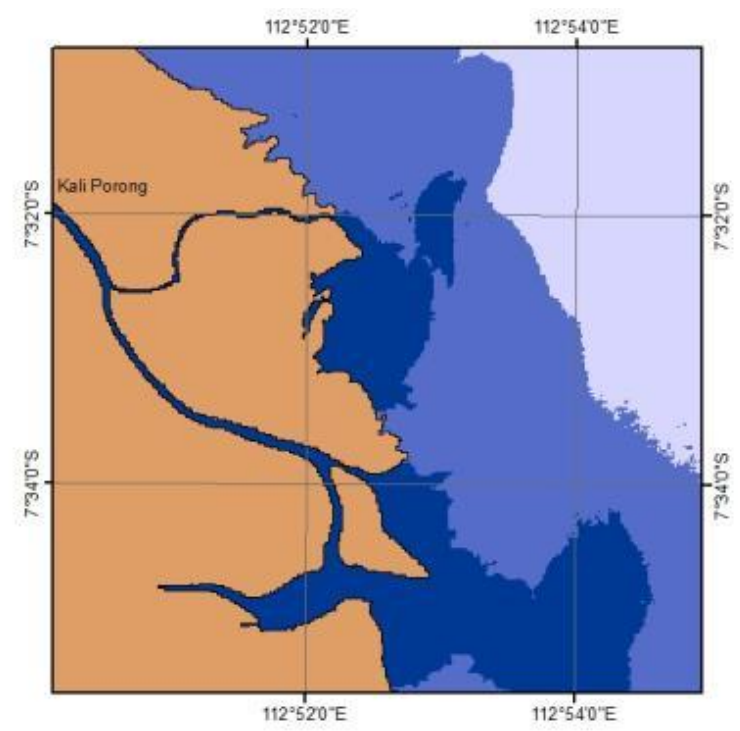

(b) Konsentrasi TSS

Gambar 13. Tingkat kecerahan dan konsentrasi TSS tahun 2017 
Tahun 2014, luas tingkat kecerahan air yang termasuk dalam kelas I didapatkan luas sebesar 1743,565 Ha. Kelas II memiliki luas 2245,909 Ha. Kelas III memiliki nilai yakni $606,021 \mathrm{Ha}$. Tingkat kecerahan air pada tahun 2015 yang memiliki kelas I didapatkan luas sebesar 1080,181 Ha. Kelas II seluas 2173,226 Ha, diikuti dengan kelas III yakni sebesar 1342,172 Ha. Tahun 2016, kelas I luas tingkat kecerahan air didapatkan luas sebesar 2002,991 Ha. Kelas II seluas 1798,671 Ha, diikuti dengan kelas III memiliki nilai luas yakni 793,882 Ha. Tahun 2017, luas tingkat kecerahan air yang termasuk kelas I didapatkan luas sebesar 1087,814 Ha. Kelas II memiliki luas sebesar 2108,802 Ha diikuti dengan kelas III memiliki nilai yakni 1398,912 Ha.

Terdapat sedikit perbedaan luas pada Gambar 10. mengenai tingkat kecerahan air dengan sebaran konsentrasi TSS tahun 2014, wilayah yang memiliki tingkat kecerahan rendah memiliki luas sebesar 606,0211 Ha sedangkan pada konsentrasi TSS tinggi sebesar 509,0561 Ha. Tahun selanjutnya yakni 2015 dapat dilihat pada Gambar 11., diketahui bahwa sebaran nilai tingkat kecerahan rendah memiliki luas sebesar 1342,172 Ha, sedangkan nilai konsentrasi TSS pada konsentrasi tinggi yakni 1323,124 Ha. Dari kedua tahun tersebut dapat dilihat perbedaan luas antara tingkat kecerahan dengan nilai konsentrasi TSS. Hal tersebut juga dialami oleh tahun 2016 Gambar 12. yang memiliki luas sebaran tingkat kecerahan rendah yakni 793,8823 Ha, sedangkan untuk luas sebaran konsentrasi tinggi sebesar 714,0765 Ha. Gambar 13. tahun 2017 memiliki nilai tingkat kecerahan rendah yakni 1398,912 Ha, sedangkan konsentrasi TSS pada konsentrasi tinggi yakni 1350,21 Ha.

Tingkat kecerahan atau kekeruhan suatu perairan dipengaruhi oleh kandungan zat padat tersuspensi. Lokasi perairan muara, seperti muara Kali Porong tingkat kecerahan perairan sangat dipengaruhi oleh zat-zat padat tersuspensi yang dibawa dari oleh buangan Lumpur Sidoarjo menuju sungai hingga sampai di muara dan sepanjang pantai Sidoarjo. Konsentrasi TSS di perairan tidak sepenuhnya menjadi penyebab rendahnya tingkat kecerahan air. Terdapat faktor lain yang juga dapat mempengaruhi suatu tingkat kecerahan air pada penelitian ini. Namun, jika dicermati pada Gambar 10. maka dapat diketahui bahwa tingkat kecerahan air tidak selalu dipengaruhi oleh Total Suspended Solid (TSS). Tingkat kecerahan memiliki nilai yang lebih besar sedikit dari pada nilai konsentrasi tinggi TSS, terdapat suatu faktor lain yang mempengaruhi tingkat kecerahan air selain TSS. Faktor tersebut yakni warna air. Tinggi nya nilai konsentrasi TSS dapat menyebabkan semakin rendahnya tingkat kecerahan suatu perairan. Sehingga di wilayah yang memiliki konsentrasi TSS tinggi akan semakin menurun nilai tingkat kecerahannya.

Menurut Cahyadi (2016, hlm 94) pada penelitiannya, kecerahan dapat dipengaruhi oleh faktor seperti warna air, zat-zat terlarut dan partikel-partikel tersuspensi. Berdasarkan pengamatannya, warna air Waduk Darma yaitu hijau yang berarti waduk tersebut memiliki kategori perairan eutrofik. Sedangkan menurut Hamuna (2018, hlm 36) rendahnya tingkat kecerahan suatu perairan bergantung pada banyaknya suplai sedimen dan partikel terlarut, bahan organik dan anorganik yang melalui aliran run off dari daratan sehingga menyebabkan tingkat kecerahan perairan menjadi rendah dan tingkat kecerahan semakin tinggi. Selain itu, Pujiastuti (2013) juga menjelaskan pada penelitiannya bahwa kecerahan suatu perairan sangan dipengaruhi oleh keberadaan padatan tersuspensi, zat-zat terlarut, partikel-partikel, dan warna air.

\section{SIMPULAN}

1. Perubahan sebaran konsentrasi Total Suspended Solid (TSS) di muara Kali Porong dari tahun 2014-2017 memiliki nilai yang naik turun di tiap tahunnya. Kelas III tahun 2014 sebaran sebesar 509,056 Ha, tahun selanjutnya naik menjadi 1323,124 Ha. Sedangkan pada tahun 2016 sebaran konsentrasi TSS turun menjadi 714,076 Ha. Kembali naik pada tahun 2017 yakni menjadi 1350,210 Ha, yang merupakan sebaran TSS tersebesar pada selang tahun penelitian. Hal tersebut menyebabkan nilai sebaran konsentrasi TSS mengalami fluktuasi.

2. Jarak sebaran konsentrasi Total Suspended Solid (TSS) dihitung dengan titik pusat pada 3 muara. Muara 3 menjadi 
muara yang selalu memiliki nilai jarak sebaran TSS yang tertinggi. Muara 3 tahun 2017 menjadi muara yang memiliki jarak terjauh dari penelitian ini yakni 4,295 km.

3. Tingkat kecerahan sebagai ukuran transparansi suatu perairan, hasil perhitungan didapatkan nilai rentang tingkat kejernihan di wilayah muara Kali Porong yaitu 4,561 m - 15,432 m sesuai kelas konsentrasi tingkat kejernihan airnya.

\section{REKOMENDASI}

Adapun rekomendasi yang dapat disampaikan agar penelitian selanjutnya dapat lebih baik yakni perlu dilakukannya suatu penelitian lanjutan mengenai data tingkat kecerahan suatu perairan beserta faktor-faktor yang mempengaruhinya.

\section{DAFTAR PUSTAKA}

Arief, M. 2012. Pemetaan Muatan Padatan Tersuspensi Menggunakan Data Satelit Landsat. Jurnal Penginderaan Jauh Vol. 9 No.1 Juni 2012 : 67-75. Peneliti Pusat Pemanfaatan Penginderaan Jauh: Jakarta.

Budhiman, S. 2004. Mapping TSM Concentrations from Multisensor Satellite Images in Turbid Tropical Coastal Waters of Mahakam Delta. Thesis. International Institute for GeoInformation Science and Earth Observation: Netherlands.

Budianto, S, dan T. Hariyanto. 2017. Analsis Perubahan Konsentrasi TSS Dampak Bencana Lumpur Sidoarjo Menggunakan Citra Landsat Multi Temporal (Studi Kasus: Sungai Porong, Sidoarjo). Jurnal Teknik ITS Vol. 5, No. 1. (2017) ISSN: 2337-3539 (2301-9271 Print). Jurusan Teknik Geomatika, Fakultas Teknik Sipil dan Perencanaan, ITS : Surabaya.

Cahyadi, E. Masyamsir, dan Rizal, A. 2016. Kajian Variabel Kualitas Air dan Hubungannya dengan Produktivitas Primer Fitoplankton di Perairan Waduk Darma Jawa Barat. Jurnal Perikanan
Kelautan Vol. III No. 1 (93-102). Universitas Padjajaran: Bandung.

Ferdiaz, S. (1992). Polusi Air dan Udara. Kanisius: Yogyakarta.

Hamuna, B. (2018). Kajian Kualitas Air Laut dan Indeks Pencemaran Berdasarkan Parameter Fisika-Kimia Di Perairan Distrik Depapre, Jayapura. Jurnal Ilmu Lingkungan (2018), 16 (1): 35-43. Jurusan Ilmu Kelautan dan Perikanan, Universitas Cendrawasih: Papua.

Krisnayanti. B.D., dan D.S. Agustawijaya. 2014. Characteristics of Lusi Mud Volcano and its Impacts on The Porong River. Journal of Degraded and Mining Lands Management ISSN: 2339-076X, Volume 1, Number 4 (July 2014): 207210. Faculty of Agriculture, University of Mataram: Mataram.

Mujito, M., H. Riyanto, A.G Tjiptono, Suliantara, R.K. Risdianto, dan Sudianto. 1997. Evaluasi Penginderaan Jauh untuk Studi Dasar Lingkungan Wilayah Kerja UNOCAL Indonesia Company Kalimantan Timur. Bidang Litbangtek Eksplorasi. Pusat Penelitian dan Pengembangan Teknologi Minyak dan Gas Bumi, LEMIGAS: Jakarta.

Pahlevi, A.M., dan Wiweka. 2010. Analisa Sedimentasi di Muara Kali Porong Akibat Pembuangan Lumpur Lapindo Menggunakan Data Citra Satelit ASTER. Jurnal Ilmiah Geomatika Vol. 16 No.2. LAPAN: Jakarta.

Pujiastuti, P. Ismail, B, dan Pranoto. 2013. Kualitas dan Beban Pencemaran Perairan Waduk Gajah Mungkur. Jurnal EKOSAINS Vol. V. No. 1 Maret 2013. Fakultas MIPA Kimia, Universitas Sebelas Maret: Surakarta. 